\title{
Somatic growth effects of intramuscular injection of growth hormone in androgen-treated juvenile Nile tilapia, Oreochromis niloticus (Perciformes: Cichlidae)
}

\author{
Marco A. Liñán-Cabello ${ }^{1 *}$, Cindy M. Robles-Basto ${ }^{1} \&^{\dagger}$ Alfredo Mena-Herrera ${ }^{1}$ \\ 1. Acuacultura/Biotecnología, FACIMAR, Universidad de Colima, Km 19.5. Carretera Manzanillo-Barra de Navidad, \\ Manzanillo, Colima, México; linanm@ucol.mx, cindi.robles@hotmail.com \\ * Corresponding author
}

Received 09-XI-2011. C Corrected 20-VIII-2012. Accepted 18-IX-2012.

\begin{abstract}
Little is known about the effects of the interaction of growth hormone (GH) with $17 \alpha$-methyltestosterone (17-MT) during fish growth. We evaluated this in the present study to assess the effect on fish growth. Fish in two batches of juvenile tilapia (Oreochromis niloticus) (approximately $5.0 \mathrm{~cm}$ in length) were randomly assigned in triplicate to three treatments and a control group, distributed among 12 fiberglass tanks of $1000 \mathrm{~L}$ capacity (50 fish per tank) in an experiment covering a period of six weeks. The experimental groups were: a) fish treated with 17-MT and GH in mineral oil (RGH); b) fish treated with 17-MT and mineral oil without the addition of GH (R); c) fish treated with GH in mineral oil but not 17-MT (NGH); and d) fish of the control group, which were treated with mineral oil but not 17-MT or GH (N). The GH was injected into the fish at a rate of $0.625 \mathrm{mg} / \mathrm{g}$ body weight. Morphometric data were recorded at the beginning of the experiment $\left(\mathrm{T}_{0}\right)$ and at 15 , 30 and 45 days $\left(\mathrm{T}_{15}, \mathrm{~T}_{30}\right.$ and $\mathrm{T}_{45}$ ), and various indicators of growth were assessed: condition factor (K); survival percentage (S), feed conversion rate (FCR), percentage weight gain (WG) and (v) daily weight gain. The optimum dietary level was calculated assuming $5 \%$ food conversion to total weight in each group. During the experiment, the fish were provided with a commercial food containing $45 \%$ protein. The data showed that $\mathrm{GH}$ injection resulted in a greater weight gain in fish treated with 17-MT (the RGH treatment group), being particularly significant increase in weight during $\mathrm{T}_{15}$ and $\mathrm{T}_{30}(\mathrm{p}<0.05)$. High values of $\mathrm{K}$ were found in the $\mathrm{R}$ and $\mathrm{RGH}$ treatments during the initial days of the experiment, which may have been a consequence of the better nutritional status affecting both weight gain and growth in body length, as a result of the additive effects of 17-MT and GH. The fish in groups not treated with 17-MT and treated with 17-MT and added GH showed greater increases in WG per day, higher K values and lower FCRs than fish in the other groups, which suggests that greater feed efficiency occurred in the hormone-treated fish. Fish in the RGH treatment showed the most growth, suggesting a possible interaction between 17-MT and injected GH. Rev. Biol. Trop. 61 (1): 203-212. Epub 2013 March 01.
\end{abstract}

Key words: GH, tilapia, $17 \alpha$-methyltestosterone, growth, condition factor, culture.

Tilapia (O. niloticus) is widely cultivated, and commercial production of this fish will increase in the future (FAO 2007). This species has physiological and immunological tolerance to a wide range of environmental conditions, uses low protein diets efficiently, and is highly resistant to stress and infection (El-Sayed 2006, $\mathrm{Ng} \&$ Hanim 2007). These attributes make tilapia an excellent fish for laboratory studies, including those related to reproductive biology and growth (Stickney 2000, Lacerda et al. 2006), providing knowledge that can be applied to improving growth rates in the aquaculture of a diversity of fish species.

The gender of fish can be manipulated by treatment with the androgen $17 \alpha$-methyltestosterone (17-MT), but the mechanism of hormonal action remains controversial. Treated fish become masculinized, and an anabolic effect of the hormone that enhances overall growth and protein synthesis (particularly myofibrillar proteins) is evident, and results 
in greater muscle mass gain by males relative to females (Guerrero 1975, Hanson et al. 1983, Macintosh et al. 1985, McAndrew \& Majumdar 1989). The 17-MT affects the expression of secondary sexual characteristics and the appearance of the testes and ovaries (Arboleda-Obregon 2005). It has been reported (Okoko 1996, Phelps \& Popma 2000) that the use of androgens at high doses causes atrophy of secondary sexual features, possibly via an interaction with other compounds. Similarly, high doses of exogenous androgens suppress the release of gonadotropins, which has similar consequences to those previously mentioned (Ankley \& Johnson 2004, Kristensen et al. 2005).

In some countries sex reversal in culture systems has been commonly used and accepted as a means of controlling sexual reproduction in tilapia (De Silva et al. 2004, López et al. 2007), but the specific effect of 17-MT and other hormones on the time required for fish to reach commercial weight has not been widely studied (Zhou et al. 2009).

Somatotropin (or growth hormone; GH) is known to enhance the transport of amino acids across cell membranes, and also induces the release of fatty acids from adipose tissue, thus increasing the fatty acid concentration in body fluids. Furthermore, all tissues are stimulated to convert fatty acids into acetyl coenzyme A (acetyl-CoA), which is subsequently used as an energy source in preference to carbohydrates and proteins.

Growth hormone treatment $(0.5 \mu \mathrm{g} / \mathrm{g})$ has also been shown to significantly stimulated gill $\mathrm{Na}^{+} / \mathrm{K}^{+}$-ATPase activity (McCormick 2001). The tilapia prolactins PRL177 and PRL188 both increase plasma osmolality in $100 \%$ seawater, and reduce gill $\mathrm{Na}^{+} / \mathrm{K}^{+}$-ATPase activity, although the effects of PRL188 were greater than those of PRL177 (Sakamoto et al. 1997). Thus, GH may be involved in seawater adaptation in tilapia (a species belonging to the most advanced teleost superorder, Acanthopterygii), whereas neither PRL is involved in this process. Bolton et al. (1987) found that a single injection of rainbow trout (Oncorhynchus mykiss) with $\mathrm{GH}$, followed two days later by exposure to seawater, resulted in increased salinity tolerance. This time course was too rapid to be explained by change in body size, and it was suggested that GH has osmoregulatory actions independent of its effect on growth.

Exogenous GH has been shown to effectively stimulate weight gain in Coho salmon (Oncorhynchus kisutch; Down et al. 1989, McLean et al. 1994), rainbow trout (Moriyama et al. 1993, De Yong et al. 1994), Atlantic salmon (Salmo salar; Boeuf et al. 1989) and bream (Sparus aurata; Cavari et al. 1993). Mancera \& McCormick (1998) found that both GH and insulin-like growth factor 1 (IGF-1) injections increased salinity tolerance in the intertidal mummichog, Fundulus heteroclitus (Family Cyprinodontidae). Although these represent a small number of the euryhaline species, they are widely separated in terms of the evolution of teleosts, suggesting that the osmoregulatory action of GH and IGF-1 may also be widespread among teleosts (McCormick 2001). Few studies on the effects of addition of $\mathrm{GH}$ to Nile tilapia cultures have been reported (Fragoso et al. 1999).

In this study we investigated the interactive effects of GH and 17-MT on tilapia, contributing to clarification of the physiological effects of these chemicals in this model fish species, and providing fundamental knowledge of relevance to the physiology of growth in other fish.

\section{MATERIALS AND METHODS}

Newly hatched tilapia were used in all experiments, which were conducted in the Aquaculture Center of Jala (ACJ), Colima, Mexico. As described by Phelps \& Popma (2000), the hormone 17-MT (98\% w/w; Chemical Lab ARGENT, Inc. Redmond, WA, USA) was dissolved in ethanol to a concentration of $0.14 \mathrm{mg} / \mathrm{L}$, and was added to $2.4 \mathrm{~kg}$ of concentrated feed powder containing $500 \mathrm{~g}$ protein $/ \mathrm{kg}$. The fish were fed every hour for $10 \mathrm{~h}$ each day over 28 days, and the feed ratio was adjusted 
(25-8\%) according to the criteria described by Arboleda-Obregon (2005).

A total of 340 17-MT-treated and 340 non-treated $O$. niloticus were transported to the aquaculture laboratory facilities of the Faculty of Marine Sciences, University of Colima (Mexico), and quarantined for 15 days. After an acclimatization period the fish, which averaged $2.03 \pm 0.25 \mathrm{~g}($ mean $\pm \mathrm{SD})$, were randomly distributed among 12 fiberglass tanks of 1 000L capacity (50 fish per tank). The experiment lasted for a period of six weeks, and each treatment and the control were replicated (three replicate tanks per treatment/control).

The experimental treatments were: a) fish treated with 17-MT and GH in mineral oil (RGH); b) fish treated with 17-MT and mineral oil without the addition of GH (R); c) fish treated with GH in mineral oil but not 17-MT (NGH); and d) fish of the control group, which were treated with mineral oil but not 17-MT or GH $(\mathrm{N})$. In all treatments the specimens were injected intramuscularly in the dorsal region of the body.

Recombinant human GH (Humatrope ${ }^{\circledR}$; Eli Lilly and Co., Windlesham, England) was injected as a single intramuscular dose $(5 \mu \mathrm{g} / \mathrm{g}$ body weight) following solubilization in mineral oil, as described by Fragoso et al. (1999), who reported that this concentration of bovine somatotropin had the greatest effect on the growth of hybrid tilapia (Oreochromis mossambicus' O. niloticus).

The optimum feeding level was calculated assuming 5\% food conversion to total weight in each group. In the first four weeks of the experiment a commercial food (Belenes ${ }^{\circledR}$,
Winfish 45 121, Guadalajara, México) was provided. This contained (per kilogram) $450 \mathrm{~g}$ protein, $120 \mathrm{~g}$ lipid, $40 \mathrm{~g}$ fiber, $10 \mathrm{~g}$ ash, $170 \mathrm{~g}$ nitrogen-free extract and $120 \mathrm{~g}$ moisture. When the fish attained a mean weight of $12 \mathrm{~g}$ the food was changed to a pelletized form comprising the same percentage composition, at the same nutrient composition per kilogram and was added four times daily (08:00, 12:00, 16:00 and 20:00h).

Morphometric data were recorded at the beginning of the experiment $\left(\mathrm{T}_{0}\right)$ and at 15 , 30 and 45 days $\left(T_{15}, T_{30}\right.$ and $\left.T_{45}\right)$. The weight and size of all fish in each treatment and the control were recorded, and various parameters were calculated as follows: (i) condition factor $(\mathrm{K})=$ final weight/(total length $)^{3} \times 100$; (ii) survival percentage $(S)=$ final number of fish/initial number of fish $\times 100$; (iii) feed conversion rate $(\mathrm{FCR})=$ feed consumed $(\mathrm{g}) /$ weight gain $(\mathrm{g})$; (iv) percentage weight gain (WG) $=100 *$ (final weight-initial weight)/initial weight; and (v) daily weight gain $(\mathrm{Pg} ; \mathrm{wg} / \mathrm{d})=\Sigma \mathrm{wg} / \mathrm{d}$.

The culture water (average temperature $28 \pm 2.5^{\circ} \mathrm{C}$, table 1) was obtained from the municipal water system. The water was aerated and $50 \%$ of the volume was changed weekly by gradual addition. Debris was removed daily from the tanks. Chemical parameters including $\mathrm{pH}$, ammonia $\left(\mathrm{NH}_{3}\right)$ and nitrite $\left(\mathrm{NO}_{2}^{-}\right)$levels were measured weekly using a freshwater aquaculture test kit (Lamotte ${ }^{\circledR}$; Chestertown, Maryland, USA). Temperature and oxygen levels were assessed every two days using standard methods.

The Bartlett and Kolmogorov-Smirnov tests were used (Zar 1994) to assess the data

TABLE 1

Mean values for physicochemical parameters determined at times $\mathrm{T}_{0}, \mathrm{~T}_{15}, \mathrm{~T}_{30}$ and $\mathrm{T}_{45}$ in the various experimental treatments

\begin{tabular}{lcccc}
\multicolumn{1}{c}{ Parameter } & $\mathrm{RGH}$ & $\mathrm{R}$ & $\mathrm{NGH}$ & $\mathrm{N}$ \\
Temperature $\left({ }^{\circ} \mathrm{C}\right)$ & $28 \pm 2$ & $28 \pm 3$ & $28 \pm 2$ & $28 \pm 3$ \\
Dissolved oxygen $(\mathrm{mg} / \mathrm{L})$ & $3.29 \pm 0.02$ & $3.68 \pm 0.05$ & $3.76 \pm 0.05$ & $3.05 \pm 07$ \\
Total ammonia Nitrogen $(\mathrm{mg} / \mathrm{L})$ & $0.2 \pm 0.04$ & $0.2 \pm 0.03$ & $0.2 \pm 0.02$ & $2 \pm 0.03$ \\
Salinity $(\mathrm{ppm})$ & $0.5 \pm 0.02$ & $0.5 \pm 0.03$ & $0.5 \pm 0.03$ & $0.5 \pm 0.02$ \\
$\mathrm{pH}$ & $8.7 \pm 0.7$ & $8.9 \pm 0.5$ & $8.6 \pm 0.6$ & $8.6 \pm 0.4$ \\
\hline
\end{tabular}


for independence, normality and homogeneity. A two-way nested ANOVA was used to test for differences in weight, length, condition factor and feed conversion ratios among treatments. Means were compared and ranked using Tukey's multiple range test, and the significance level was set at $\mathrm{p}<0.05$. All statistical analyses were performed using Statistica ${ }^{\circledR}$ version 6.0.

\section{RESULTS}

No significant differences in mean weight were found among the groups at $\mathrm{T}_{0}$ (Fig. 1). At $\mathrm{T}_{15}$ significant differences among treatments were observed ( $\mathrm{p}=0.032)$, with the mean weight of fish in the RGH treatment being greater than in the other treatments, and the R group having the lowest mean weight. At $T_{30}$ the fish in the two GH groups had mean weights greater than in the other treatments, with the mean weight of fish in the RGH treatment being greatest. The mean weight in the $\mathrm{R}$ treatment was significantly lower than in the other treatments at this time. At $\mathrm{T}_{45}$ the mean weights were greater in the NGH and RGH treatment groups, which were not significantly different $(\mathrm{p}=0.09)$.

Fish in the RGH treatment showed the greatest weight gain, followed by those in

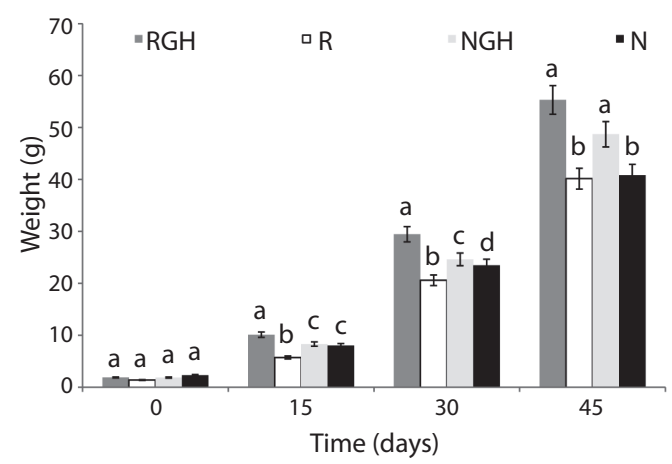

Fig. 1. Mean weight of fish over time in various treatments. Letters show data that are of equal variance but significantly different $(\mathrm{p}<0.05$; all data are mean \pm standard error $)$. the NGH treatment, whereas fish that did not receive GH had a lower mean weight gain. Figure 1 shows that the maximum weight gain occurred between $\mathrm{T}_{30}$ and $\mathrm{T}_{45}$. In this interval the mean weight gain in fish in the RGH treatment was $25.86 \mathrm{~g}$. The lowest weight gain occurred in the period between $\mathrm{T}_{0}$ and $\mathrm{T}_{15}$, during which mean weight gain of fish in the $\mathrm{R}$ treatment was $4.34 \mathrm{~g}$.

The mean values of the physicochemical parameters measured were very similar and varied little among treatments (Table 1). Fish mortality was lower in the treatments not involving the androgen (2\% and $8 \%$ in the $\mathrm{NGH}$ and $\mathrm{N}$ treatments, respectively), whereas 32 fish $(21.4 \%)$ died in the $\mathrm{R}$ group. The rate of weight gain was greatest for fish in the RGH treatment (mean $1.23 \mathrm{~g}$ /day), whereas fish in the NGH treatment gained $1.08 \mathrm{~g} /$ day (mean), and those in the $\mathrm{N}$ and $\mathrm{R}$ treatments gained less weight (Table 2).

The greatest value for the condition factor was found in the RGH treatment followed by the $\mathrm{R}$ treatment (2.32 and 2.24, respectively). However, a plot of this parameter throughout the experiment indicated major fluctuations: in the RGH treatment $\mathrm{K}$ increased to 2.45 at $\mathrm{T}_{15}$, decreased to $\mathrm{T}_{30}$, and then increased to 2.3 at $\mathrm{T}_{45}$ (Fig. 2). A similar trend but with lower amplitude and a greater value at $\mathrm{T}_{30}$ occurred in treatment $\mathrm{R}$. The mean values for the measured physicochemical parameters in the various treatments are shown in table 2 .

\section{DISCUSSION}

The use of steroids as masculinizing agents in tilapia culture has been reported to be 90-100\% efficient in Sarotherodon niloticus, O. mossambicus and O. niloticus (Tayamen \& Shelton 1978, Pandian \& Varadaraj 1988 and Jiménez-Badillo \& Arredondo-Figueroa 2000, respectively). However, some studies have shown that 17-MT alters the morphology and histological architecture of male gonads (Baatrup \& Junge 2001, Ankley \& Johnson 2004, Kristensen et al. 2005). Specifically, sexually reversed females have intersex gonads, reduced 
TABLE 2

Tilapia experimental parameters: initial and final weight, percentage weight gain, growth rate, survival, weight gain per day, feed conversion ratio and conversion factor

\begin{tabular}{lcccc}
\multicolumn{1}{c}{ Parameter } & RGH & $\mathrm{R}$ & $\mathrm{NGH}$ & $\mathrm{N}$ \\
Initial weight (g) & $1.89 \pm 0.22^{\mathrm{a}}$ & $1.39 \pm 0.18^{\mathrm{a}}$ & $1.86 \pm 0.24^{\mathrm{a}}$ & $2.32 \pm 0.33^{\mathrm{a}}$ \\
Final weight (g) & $55.32 \pm 8.6^{\mathrm{a}}$ & $40.15 \pm 6.3^{\mathrm{b}}$ & $48.71 \pm 11.2^{\mathrm{a}}$ & $40.84 \pm 8.3^{\mathrm{b}}$ \\
Percentage weight gain (\%) & $2832 \pm 15^{\mathrm{a}}$ & $2792.8 \pm 387^{\mathrm{a}}$ & $2520.7 \pm 587^{\mathrm{a}}$ & $1663.4 \pm 45^{\mathrm{b}}$ \\
Weight/gain (g/day) & $1.23 \pm 0.36^{\mathrm{a}}$ & $0.89 \pm 0.23^{\mathrm{b}}$ & $1.08 \pm 0.31^{\mathrm{a}}$ & $0.91 \pm 0.21^{\mathrm{b}}$ \\
Feed Conversion Ratio & $1.75 \pm 0.35^{\mathrm{a}}$ & $1.90 \pm 0.33^{\mathrm{b}}$ & $1.77 \pm 0.28^{\mathrm{a}}$ & $1.81 \pm 0.12^{\mathrm{a}}$ \\
Condition Factor & $2.322 \pm 0.25^{\mathrm{b}}$ & $1.919 \pm 0.22^{\mathrm{a}}$ & $2.244 \pm 0.15^{\mathrm{ab}}$ & $1.96 \pm 0.17^{\mathrm{a}}$ \\
Survival (\%) & $83.33 \pm 7.1^{\mathrm{b}}$ & $78.67 \pm 8.5^{\mathrm{b}}$ & $97.33 \pm 3.1^{\mathrm{a}}$ & $98.00 \pm 2.5^{\mathrm{a}}$ \\
\hline
\end{tabular}

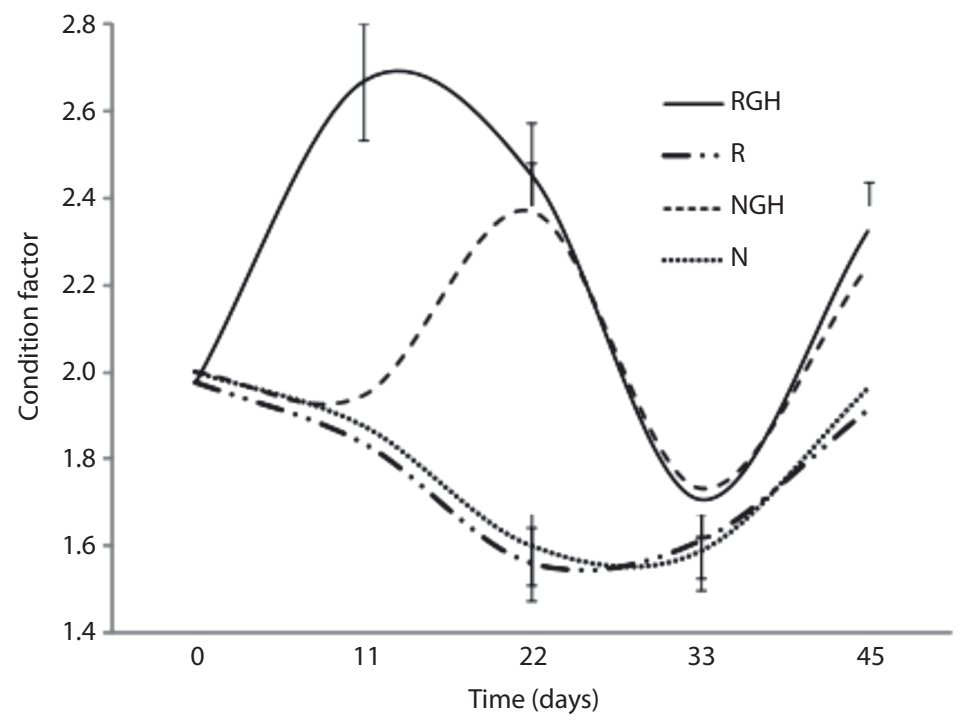

Fig. 2. Mean condition factor $(\mathrm{K})$ during the experimental culture of $O$. niloticus under various conditions.

fertility (Ankley \& Johnson 2004, Kristensen et al. 2005), and changed concentrations of circulating hormones and vitellogenin (Ankley \& Johnson 2004). Similarly, enhanced myofibrillar protein synthesis has been found in sexually reversed specimens (McAndrew \& Majumdar 1989), resulting in greater gains in the muscle mass of male fish relative to females. According to Okoko (1996) and Phelps \& Popma (2000), hormonal action is compromised by environmental factors; the hormone can be degraded by increased temperature, sunlight or a change in salinity, which results in chemical modification of the compound or promotes co-precipitation of the hormone with salts (Tayamen \&
Shelton 1978). However, in the present study we maintained the fish under stable environmental conditions during the reversal process (Table 1), including a temperature of approximately $28 \pm 2.5^{\circ} \mathrm{C}$, low salinity $(0.5 \mathrm{ppm})$, and high levels of oxygenation. Thus, variations in environmental conditions did not affect our results, and the only variable in the experiment was intraperitoneal GH treatment.

In our study, the non-androgen-treated and androgen-treated groups with added GH showed greater increases in weight gain per day, higher $\mathrm{K}$ values and lower feed conversion rates, which suggests greater feed efficiency in the hormone-treated fish. There is some 
controversy regarding the effects of GH on the FCR. Thus, in some studies no differences have been observed in the FCR in specimens treated with GH relative to controls (Fragoso et al. 1999). In other studies greater consumption of food in fish treated with $\mathrm{GH}$ has been observed with no improvement in the FCR (Seddiki et al. 1996) and, consistent with the results of the present study, there have been reports of lower FCRs in various species of fish fed GH (Ishioka et al. 1992, Zhang 1993, Johnson \& Björnsson 1994, Garber et al. 1995, Picha et al. 2008). In addition, it has been suggested that variables such as temperature, size, species and diet may affect protein accretion (Markert et al. 1977). However, some studies have suggested that in rainbow trout somatotropin stimulates repartitioning (i.e., greater retention of ingested nitrogen and increased protein synthesis rates) in a similar way to that which occurs in cattle treated with somatotropin (Garber et al. 1995). Our results regarding optimization of the FCR in the GH treatment group extends such observations to tilapia.

Growth-promoting mechanisms are initiated in the neuroendocrine system, and the modulators interact with hormones of the hypothalamus, pituitary gland and gonads (MuñozCueto 2005). This process involves expression of GH and sexual hormones, including testosterone in males and estradiol in females. Our results showed that the effect of GH was most evident from $\mathrm{T}_{15}$, and that the mean weight (as an indicator of growth) was enhanced in fish in both the RGH and NGH treatments. In addition, the fish in the $\mathrm{RGH}$ treatment had the greatest weight gain, and the highest $\mathrm{K}$ and FCR values. Fragoso et al. (1999) injected tilapia intramuscularly with $\mathrm{GH}$, and the weight gain that was not sexually reversed began to fall in week six of their experiment. Similarly, in both treatments in which the fish were treated with GH in our experiment, the fish had more growth at week six compared with those that were not treated with this hormone.

There is much variability in the reported growth rates of tilapia because of the various environmental, nutritional and genetic factors that influence somatic development. CastroRivera et al. (2004) reported a weight gain of $0.205 \mathrm{~g}$ /day when fish were cultured in hard water; Ergün et al. (2009) reported a weight gain of $0.171 \mathrm{~g} /$ day in fish fed a diet enriched with crude lipid flour and meal prepared from the alga Ulva spp.; Hernández et al. (2010) found growth rates of 0.441 and $0.67 \mathrm{~g} /$ day in fish fed a control diet and a diet enriched with meal of porcine origin, respectively; and PootDelgado et al. (2009) found that the growth rate of juvenile tilapia increased to $0.624 \mathrm{~g}$ /day on a diet containing $43 \%(\mathrm{w} / \mathrm{w})$ protein. It is noteworthy that the above figures are all lower than those we observed in fish in the RGH and NGH treatments (1.18 and $1.04 \mathrm{~g} /$ day, respectively), although in most previous reports were used systems with high water exchange flows with strict temperature control. In our study, only $50 \%$ of the water volume was changed each week, and the water quality was not strictly controlled (the water came from the municipal network). In this regard, studies of various fish species have emphasized the importance of maintaining a high temperature if $\mathrm{GH}$ effects are to be optimal (Ricordel et al. 1995, Deane \& Woo 2005). According to Deane \& Woo (2009), temperature affects regulation of fish growth hormone receptors, and thus it is quite possible that we would have observed higher growth rates had we strictly controlled the temperature.

From the results presented it is evident that $\mathrm{GH}$ injection resulted in a greater weight gain in 17-MT-treated fish (the RGH treatment group), and the difference was significant at both $T_{15}$ and $\mathrm{T}_{30}$ ( $\mathrm{p}<0.05$ for both comparisons). Similarly, high values of $\mathrm{K}$ occurred in the $\mathrm{R}$ and RGH treatments during the first days of culture. This may have been associated with the better nutritional status affecting both weight development and fish body length, as a result of the additive effects of 17-MT and GH. However, it is also possible that as the fish metabolized the added hormone, and when high concentrations of androgen compounds are reduced, decreases the possible effect of hormonal interaction. In this regard it is quite possible that some of the 
apparent growth effects of anabolic steroids are mediated by other hormones. For instance, exogenous androgens are able to stimulate growth hormone and prolactin release from the pituitary of tilapia (O. mossambicus) (Shepherd et al. 1977), and thyroid hormone delivery (Hunt \& Eales 1979). According to Holloway \& Leatherland (1997), implants of testosterone and $17 \beta$-estradiol increase plasma growth hormone titers, although the effect is greater with $17 \beta$-estradiol.

In this regard it is noteworthy that it has been proposed that an interaction occurs between the somatotroph and gonadotroph hormonal axes, represented by 17-MT and GH (Holloway \& Leatherland 1998, Holloway et al. 2000, Kaiya et al. 2003, Muñoz-Cueto 2005, Zhou et al. 2009). Thus, receptor levels must be upregulated for tissue growth to be affected. However, supporting molecular evidence for this suggestion is lacking. It is known that steroids such as 17-MT act as growth promoters in carp (Manzzor \& Satyanarayana 1989, Kuwaye et al. 1993). O. mossambicus tilapia cultured in freshwater or seawater gained more weight when 17-MT was administered (Kuwaye et al. 1993, Ron et al. 1995). Between $T_{15}$ and $T_{30}$ the growth of the fish treated with 17-MT was significantly less than in the control treatment. In this regard, in the experiments described above the action of 17-MT as a growth promoter involved juveniles fed fish food dosed with 17-MT. In our experiment, we used specimens that had recently been treated with 17-MT, which may have affected the expression of secondary sexual characteristics and the appearance of testes and ovaries, and induced a state of physiological stress as a consequence of the atrophy of secondary sexual characteristics (Phelps \& Popma 2000, Arboleda-Obregon 2005). This could explain the growth reduction in fish in the $\mathrm{R}$ treatment with respect to the control fish.

In the early part of the experiment we observed a greater effect on growth and physiological condition in treatments comprising fish that had been sexually reversed with 17-MT treatment and dosed with GH, suggesting an interaction of these treatments. However, this effect was observed only for a limited period, possibly because the fish metabolized the compounds and reached a natural state of endocrine function. To expand knowledge of the physiology of fish growth, an experiment of longer duration is required to explore the effects and interactions of 17-MT and GH at the molecular level.

\section{ACKNOWLEDGMENTS}

This project was supported by Aquaculture \& Biotechnology Department of the Faculty of Marine Sciences, the University of Colima. We are grateful to Scott Butler (Managing Editor, English Manager Science Editing) for reviewing the language.

\section{RESUMEN}

Actualmente, durante el crecimiento de los peces existe poco conocimiento sobre los efectos de la interacción de la hormona del crecimiento (HC) con 17 $\alpha$-metiltestosterona (17-MT). En el presente estudio los peces en dos lotes de tilapia (Oreochromis niloticus) $(\approx 5.0 \mathrm{~cm}$ de longitud), fueron asignados al azar por triplicado a tres tratamientos y un grupo control, distribuidos en 12 tanques de fibra de vidrio de 1000 litros (50 peces por tanque), en un período de seis semanas. Los tratamientos fueron: a) peces tratados con 17-MT $+\mathrm{HC}$ en aceite mineral (RGH), b) peces tratados con 17-MT+aceite mineral sin la adición de $\mathrm{HC}(\mathrm{R}), \mathrm{c})$ los peces que no fueron tratados con 17-MT-tratado+HC en aceite mineral (NGH), y d) los peces que no fueron tratados con 17-MT+aceite mineral (N). La hormona de crecimiento humano recombinante (Humatrope ${ }^{\circledR}$, Eli Lilly \& Co., Windlesham, Inglaterra), se inyectó en el pez con una dosis de $0.625 \mathrm{mg}$ por gramo de peso corporal. Los datos morfométricos se registraron al comienzo del experimento $\left(\mathrm{T}_{0}\right)$ y en los días 15,30 y $45\left(\mathrm{~T}_{15}, \mathrm{~T}_{30} \mathrm{y} \mathrm{T}_{45}\right)$, Se registraron diversos indicadores de crecimiento: factor de condición $(\mathrm{K})$, porcentaje de supervivencia (S), la tasa de conversión alimenticia (FCR), porcentaje de ganancia de peso (GP) y el aumento de peso al día. El nivel óptimo dietético fue calculado suponiendo $5 \%$ de conversión de alimentos al peso total de cada grupo. Durante el experimento fue usada una dieta comercial con el $45 \%$ de proteína. De los resultados presentados, es evidente que la inyección de $\mathrm{HC}$ dio lugar a una mayor ganancia de peso en el 17-MT-los peces tratados (el grupo de tratamiento $\mathrm{RGH}$ ), y la diferencia fue significativa, tanto en $\mathrm{T}_{15}$ y $_{30}(\mathrm{p}<0.05)$ para ambas comparaciones. De manera similar, los altos valores de $\mathrm{K}$ se presentaron en los 
tratamientos R y RGH durante los primeros días de cultivo. Esto puede haber sido asociado con un mejor estado nutricional que afectó tanto el desarrollo de peso y la longitud del cuerpo del pez, como resultado del efecto aditivo de 17-MT y GH. Los tratamientos no andrógenos y los grupos tratados con andrógenos y con $\mathrm{HC}$ mostraron un mayor incremento en la ganancia de peso por día, los mayores valores de $\mathrm{K}$ y menores tasas de conversión del alimento, lo que sugiere una mayor eficiencia de la alimentación en los peces tratados con hormonas. Peces en el tratamiento RGH mostraron el mayor crecimiento, lo que sugiere una posible interacción entre el 17 de $\alpha$-metiltestosterona (17-MT) y hormona de crecimiento inyectada.

Palabras clave: $\mathrm{HC}$, tilapia, $17 \alpha$-metiltestosterona, crecimiento, factor de condición, cultivo.

\section{REFERENCES}

Ankley, G. \& R. Johnson. 2004. Small Fish Models for Identifying and Assessing the Effects of Endocrinedisrupting Chemicals. ILAR J. 4: 469- 483.

Arboleda-Obregón, D. 2005. Reversion sexual de las tilapias rojas (Oreochromis sp), una guía básica para el acuicultor. Revista Electrónica de Veterinaria (Consultado: 06 Febrero 2012, http://www.veterinaria.org/ revistas/redvet/n121205html).

Baatrup, E. \& M. Junge. 2001. Antiandrogenics Pesticides Disrupt Sexual characteristics in adult Male Guppy (Poecilia reticulata). Environ. Health Persp. 109: 1063-1070.

Boeuf, G., P. Le Bail \& P. Prunet. 1989. Growth hormone and thyroid hormones during Atlantic salmon Salmo salar L., smolting, and after transfer to seawater. Aquaculture 82: 257-268.

Bolton, J.P., N.L. Collie, H. Kawauchi \& T. Hirano. 1987. Osmoregulatory actions of growth hormone in rainbow trout (Salmo gairdneri). J. Endocrinol. 112: $63-68$.

Castro-Rivera, R., J. Hernández-Girón \& G. Aguilar-Benítez. 2004. Evaluación del crecimiento de alevines de tres especies de Tilapia (Oreochromis sp.) en aguas duras, en la región de la Cañada, Oaxaca, México. Rev. Aqua. 20: 38-43.

Cavari, B., B. Funkenstei, T. Chen, L. González-Villaseñor \& M. Schartl. 1993. Effect of growth hormone on the growth rate of the gilthead seabream (Sparus aurata) and use of different constructs for the production of transgenic fish. Aquaculture 111: 189-197.

De Silva, S.S., R.P. Subasinghe, D.M. Bartley \& A. Lowther. 2004. Tilapia as alien aquatics in Asia and the Pacific: a review. FAO Fisheries Technical Paper. No. 453, Rome, FAO.
De Yong, K., R. Roeder, M. Gaber, W. Lellis, D. Honeyfields \& R. Bull. 1994. Dose-effects of recombinant bovine somatotropin on growth performance and body composition of rainbow trout (Oncorhynchus mykiss). J. Anim. Sci. Suppl. 1: 200.

Deane, E.E. \& N.Y.S. Woo. 2005. Expression studies on glucose-6-phosphate dehydrogenase in sea bream: Effects of growth hormone, somatostatin, salinity and temperature. J. Exp. Zool. 303: 676-688.

Deane, E.E. \& N.Y.S. Woo. 2009. Modulation of fish growth hormone levels by salinity, temperature, pollutants and aquaculture related stress: a review. Rev. Fish. Biol. Fisher. 19: 97-120.

Down, N., E. Donaldson, H. Dye, T. Bone, K. Langley \& L. Souza. 1989. A potent analog of recombinant bovine somatotropin accelerates growth in juvenile coho salmon (Oncorhynchus kitsuch). Can. J. Fish. Aquat. Sci. 46: 178-183.

El-Sayed, A-F.M. 2006. Tilapia Culture. CABI, Wallingford, Oxfordshire, United Kingdom.

Ergün, S., S. Soyutürk, B. Güroy, D. Güroy \& D. Merrifield. 2009. Influence of Ulva meal on growth, feed utilization, and body composition of juvenile Nile tilapia (Oreochromis niloticus) at two levels of dietary lipid. Aquacult. Int. 17: 355-361.

FAO. Organización de las Naciones Unidas para la Agricultura y la Alimentación. 2007. Fisheries Department, Fishery Information, Data and Statistics Unit. Fishstat Plus: Vers. 2.

Fragoso, M., A. Auro de Ocampo, L. Ocampo, H. Sumano \& E. Avila. 1999. Efecto de la somatotropina recombinante bovina sobre el crecimiento de híbridos de tilapia a diferentes temperaturas. Vet. Méx. (Consultado: 06 Febrero 2012, http://redalyc.uaemex.mx/ pdf/423/42330206.pdf.).

Garber, M.J., K.G. De Yonge \& J.C. Byatt. 1995. Doseresponse effects of recombinant bovine somatotropin (Posilac) on growth performance and body composition of two-year-old rainbow trout (Oncorhynchus mykiss). J. Anim. Sci. 73: 3216-3222.

Guerrero, I.I.R. 1975. Use of androgens for the production of all male Tilapia aurea; (Steindachner). Trans. Am. Fisher. Soc. 104: 342-348.

Hanson, T., R. Smitherman, W. Shelton \& R. Dunham. 1983. Growth comparisons of monosex tilapia produced by separation of sexes, hybridization, and sex reversal, p. 570-579. In L. Fishelson \& Z. Yaron (eds.). International Symposium on Tilapia in Aquaculture, Proceedings. Tel Aviv University, Tel Aviv, Israel.

Hernández, C., M.A. Olvera-Novoa, R.W. Hardy, A. Hermosillo, C. Reyes \& B. González. 2010. Complete replacement of fish meal by porcine and poultry by-product meals in practical diets for fingerling 
Nile tilapia Oreochromis niloticus: digestibility and growth performance. Aquacult. Nut. 16: 44-53.

Holloway, A.C \& J.F. Leatherland. 1997. Estradiol inhibits plasma somatostatin 14 (SRIF-14) levels and inhibits the response of somatotrophic cells to SRIF-14 challenge in vitro in rainbow trout, Oncorhynchus mykiss. Gen. Comp. Endocr. 106: 407-414.

Holloway, A. \& L. Leatherland. 1998. Neuroendocrine regulation of growth hormone secretion in teleost fishes with emphasis on the involvement of gonadal sex steroids. Rev. Fish. Biol. Fish. 8: 1-21.

Holloway, A., T. Melroe, M. Ehrman, P.K. Reddy, J.F. Leather-Land \& M.A. Sheridan. 2000. Effect of 17 $\beta$-estradiol on the expression of somatostatin genes in rainbow trout (Oncorhychus mykiss). Am. J. Physiol. Reg. I. 279: 389-393.

Hunt, D.W.C. \& J.G. Eales. 1979. Iodine balance in rainbow trout (Salmo gairdneri) and effects of testosterone propionate. J. Fish. Res. Board Can. 36: 282-285.

Ishioka, H., R. Kosugi, K. Ouchi, H. Ishioka, R. Kosugi \& K. Ouchi. 1992. Effects of recombinant red sea bream growth hormone on growth of young red sea bream. Bull. Jap. Soc. Sci. Fisher. 58: 2335-2340.

Jiménez-Badillo, M. \& J. Arredondo-Figueroa 2000. Effect of oral treatment of synthetic androgens on sex ratio, survival and growth rates, in three strains of tilapia. Hidrobiológica 10: 115-120.

Johnson, J.I. \& B.T. Björnsson. 1994. Growth hormone increases growth rate, appetite and dominance in juvenile rainbow trout, Oncorhynchus mykiss. Anim. Behav. 47: 177-186.

Kaiya, H., M. Kojima, H. Hosoda, G. Larry, G. Rileyc \& T. Hirano. 2003. Identification of tilapia grelin and its effects on growth hormone and prolactin release in the tilapia, Oreochromis mossambicus. Comp. Biochem. Physiol. B.135: 421-429.

Kristensen, T., E. Baatrup \& M. Bayley. 2005. $17 \alpha-$ ethinylestradiol reduces the competitive reproductive fitness of the male guppy (Poecilia reticulata). Biol. Reproduct. 75: 150-156.

Kuwaye, T.T., D.K. Okimoto, S.K. Shimoda \& R.D. Howerton. 1993. Effect of 17 alpha-methyltestosterone on the growth of the euryhaline tilapia, Oreochromis mossambicus, in fresh water and in sea water. Aquaculture 113: 137-152.

Lacerda, S.M.S.N., S.R. Batlouni, S.B.G. Silva, C.S.P. Homem \& L.R. França. 2006. Germ cells transplantation in fish: the Nile-tilapia model. Anim. Reprod. 3:146-159.

López, C.A., D.L. Carvajal \& M.C. Botero 2007. Masculinización de tilapia roja (Oreochromis spp.) por inmersión utilizando $17 \alpha$-metiltestosterona. Rev. Col. Cienc. Pec. 20: 318-326.
Macintosh, D., N. Varghese \& G. Satyanarayana. 1985. Hormonal sex reversal of wild-spawned tilapia in India. J. Fish. Biol. 26: 87-94.

Mancera, J.M. \& S.D. McCormick. 1998. Evidence for growth hormone/insulin-like growth factor I axis regulation of seawater acclimation in the euryhaline teleost Fundulus heteroclitus. Gen. Comp. Endocr. 111: 103-112.

Manzzor, P. \& G. Satyanarayana. 1989. Growth improvement in carp, Cyprinus carpio (Linnaeus), sterilized with $17 \alpha$-methiltestosterone. Aquaculture 76 : 157-167.

Markert, J.R., D.A. Higgs, H.M. Dye \& D.W. MacQuarrie. 1977. Influence of bovine growth hormone on growth rate appetite, and food conversion of yearling coho salmon (Oncorhynchus mykiss) fed two diets of different composition. Can. J. Zool. 55:74-83.

McAndrew, B. \& K. Majumdar. 1989. Growth studies on juvenile tilapia using pure species, hormone-treated and nine interspecific hybrids. Aquacult. Fisher. Manag. 20: 35-47.

McCormick, S.D. 2001. Endocrine Control of Osmoregulation in Teleost Fish. Amer. Zool. 41: 781-794

McLean, E., E. Donaldson, Y. Mayer, E. Teskeredzic, Z. Teskeredzic, C. Pitt \& L.M. Souza. 1994. Evaluation of a sustained-release polymer-encapsulated form of recombinant porcine somatotropin upon long-term growth performance of coho salmon (Oncorhynchus kitsuch). Aquaculture 122: 359-368.

Moriyama, S., H. Yamamoto \& S. Sugimoto. 1993. Oral administration of recombinant salmon growth hormone to rainbow trout, (Oncorhynchus mykiss). Aquaculture 112: 99-106.

Muñoz-Cueto, J. 2005. Control Hormonal de la reproducción en peces. Departamento de Biología. Facultad de Ciencias del Mar y Ambientales. Universidad de Cádiz, Cádiz, España.

Ng, W. \& R. Hanim. 2007. Performance of genetically improved Nile tilapia compared with red hybrid tilapia fed diets containing two protein levels. Aquac. Res. 38: 965-977.

Okoko, M. 1996. Effect of 17 $\alpha$-methyltestosterone concentrations on the sex ratio, and gonadal development of Nile tilapia Oreochromis niloticus. Masters Thesis, Auburn University, Alabama, USA.

Pandian, T.K. \& K. Varadaraj. 1988. Techniques for producing all male and all-triploid Oreochromis mossambicus, p. 243-249. In R.S.V. Pullin, T. Bhukaswan, K. Tonguthai \& J.L. Maclean (eds.). The Second International Symposium on Tilapia in Aquaculture. ICLARM Conference Proceedings 15. Department of Fisheries, Bangkok, Thailand, and International Center for Living Aquatic Resources Management, Manila, Philippines. 
Phelps, R. \& T.J. Popma. 2000. Sex reversal of tilapia, p. 34-59. B.A. Costa-Pierce \& J.E. Rakocy (eds.). Tilapia Aquaculture in the Americas, Vol. 2. The World Aquaculture Society, Baton Rouge, Louisiana, USA.

Picha, M.E., M.J. Turano \& C.K. Tipsmark. 2008. Regulation of endocrine and paracrine sources of Igfs and Gh receptor during compensatory growth in hybrid striped bass (Morone chrysops X Morone saxatilis). J. Endocrinol. 199: 81-94.

Poot-Delgado, C., A. Salazar-Novelo \& M.F. HernándezHernández. 2009. Evaluación de dietas comerciales sobre el crecimiento de tilapia (Oreochromis niloticus) (Linnaeus) etapa crianza. $2^{\circ}$ Congreso Internacional de Investigación Cd. Delicias, Chihuahua, México.

Ricordel, M.J., J. Smal \& P.Y. Le Bail. 1995. Application of a recombinant cichlid growth hormone radioimmunoassay to measure native $\mathrm{GH}$ in tilapia (Oreochromis niloticus) bred at different temperatures. Aquat. Living. Resour. 8: 153-160.

Ron, B., S.K. Shimoda, G.K. Iwama \& G. Grau. 1995. Relationships among ration, salinity, $17 \alpha$-methyltestosterone and growth in the euryhaline tilapia, Oreochromis mossambicus. Aquaculture 135: 185-193.

Sakamoto, T., B.S. Shepherd, S.S. Madsen, R.S. Nishioka, K. Siharath, N.H. Richman, H.A. Bern \& E.G. Grau. 1997. Osmoregulatory Actions of Growth Hormone and Prolactin in an Advanced Teleost. Gen. Comp. Endocr. 106: 95-101.

Seddiki, H., G. Boeuf, V. Maxime \& C. Peyraud. 1996. Effects of growth hormone treatment on oxygen composition and sea water adaptability in Atlantic salmon and pre smolts. Aquaculture 148: 49-62.

Shepherd, B.S., T. Sakamoto, S.R. Nishioka, N.H. Richman, I. Mori, S.S. Madsen, T.T. Chen, T. Hirano, H.A. Bern \& E.G. Grau. 1977. Somatotropic actions of the homologus growth hormone and prolactins in the euryhaline teleost, Oreochomis mossambicus. Proc. Nat. Sci. 94: 2068-2072.

Stickney, R.R. 2000. Tilapia culture, p. 934-941. In R.R. Stickney (eds.). Encyclopedia of aquaculture. John Wiley \& Sons, New York, USA.

Tayamen, M. \& W. Shelton. 1978. Inducement of sex reversal in Sarotherodon niloticus (Linnaeus). Aquaculture 14: 349-354.

Zar, J.H. 1994. Biostatistical analysis. Prentice-Hall, Englewood Cliffs, New Jersey, USA.

Zhang, P. 1993. Effects of recombinant tuna growth hormone (R-TGH) on growth of carp fingerling. J. Fish. China 17: 230-234.

Zhou, H., Z. Tian, Y. Wang \& L. Weifen. 2009. Effect of treatment with probiotics as water additives on tilapia (Oreochromis niloticus) growth performance and immune response. Fish. Physiol. Biochem. 3: 501-509. 